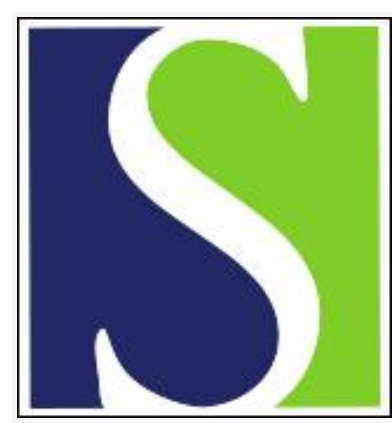

Scand J Work Environ Health 1991;17(3):208-215

https://doi.org/10.5271/sjweh.1718

Issue date: Jun 1991

Immediate and delayed allergy from epoxy resins based on diglycidyl ether of bisphenol $A$.

by Kanerva L, Jolanki R, Tupasela O, Halmepuro L, Keskinen H, Estlander T, Sysilampi ML

Affiliation: Institute of Occupational Health, Helsinki, Finland.

This article in PubMed: www.ncbi.nlm.nih.gov/pubmed/1829851 


\title{
Immediate and delayed allergy from epoxy resins based on diglycidyl ether of bisphenol A
}

\author{
by Lasse Kanerva, MD, Riitta Jolanki, MSc(ChemEng), Outi Tupasela, MSc, \\ Liisa Halmepuro, MSc, Helena Keskinen, MD, Tuula Estlander, MD, \\ Marja-Liisa Sysilampi, MD ${ }^{1}$
}

\begin{abstract}
KANERVA L, JOLANKI R, TUPASELA O, HALMEPURO L, KESKINEN H, ESTLANDER T, SYSILAMPI M-L. Immediate and delayed allergy from epoxy resins based on diglycidyl ether of bisphenol A. Scand J Work Environ Health 1991:17:208-215. This case report presents two patients with immediate and delayed allergy to epoxy resins based on diglycidyl ether of bisphenol A (DGEBA). In patch testing, the epoxy resin (DGEBA-based) of the standard series gave allergic reactions. Both patients had a prick test reaction of histamine size or larger to the human serum albumin (HSA) conjugate of DGEBAbased epoxy resins. One had been occupationally exposed to methyl tetrahydrophthalic anhydride (MTHPA) and had a histamine-size prick test reaction to the HSA conjugate of MTHPA; the other did not react to the conjugate. Determinations of specific immunoglobulin $\mathrm{E}$ were carried out with HSA-DGEBA conjugates, two DGEBA-based epoxy resins, and phthalic anhydrides. The first patient had positive tests to DGEBA, the DGEBA-based epoxy resins, and two phthalic anhydrides, and the second to DGEBA and the DGEBA-based epoxy resins, but not to the phthalic anhydrides.
\end{abstract}

Key words: allergic contact dermatitis, asthma, human serum albumin conjugated with haptens, methyl hexahydrophthalic anhydride, methyl tetrahydrophthalic anhydride, occupational, organic acid anhydride, phthalic anhydride, rhinitis.

The epoxy resin system contains a vast number of sensitizing chemicals. Epoxy resins based on diglycidyl ether of bisphenol A (DGEBA) are strong contact sensitizers $(1,2)$ and are among the most common causes of occupational allergic contact dermatitis (3-5). Lowmolecular weight polyamine hardeners are also strong contact sensitizers $(6,7)$. Anhydride hardeners, on the other hand, rarely cause delayed contact allergy (8), but are well known occupational respiratory allergens (9). Aliphatic polyamine hardeners (eg, diethylenetriamine and triethylenetetramine) can also cause occupational asthma (10) and contact urticaria (11).

Very few cases of immediate allergy from epoxy resins have been reported. In an older report a patch test with an epoxy resin induced generalized urticaria and an asthmatic reaction (12). Romaguera et al (13) described a case having hand eczema, rhinitis, and conjunctivitis caused by DGEBA-based epoxy resins. In 1983 Suhonen (14) reported two patients who had immediate urticarial patch test reactions, probably from an impure DGEBA-based epoxy resin used in the patients' workplace. The epoxy resin in the patch test standard series did not give an immediate reaction, and the causative agent was not further clarified.

\footnotetext{
${ }^{1}$ Institute of Occupational Health, Helsinki, Finland.
}

Reprint requests to: Dr L Kanerva, Section of Dermatology, Institute of Occupational Health, Topeliuksenkatu 41 a A, SF-00250 Helsinki, Finland.
During the past 15 years we have had 1622 cases of occupational dermatoses $(4,5)$. Only two cases of occupational contact urticaria were caused by chemicals of the epoxy resin system $(3,5)$. Skin tests indicated that in both cases the causative agent was methyl hexahydrophthalic anhydride (MHHPA). Recently, we have reported additional cases of occupational asthma and rhinitis caused by exposure to MHHPA (15).

In the present report, findings of two patients who had occupational immediate allergy (asthma) and delayed allergy (allergic contact dermatitis) from exposure to DGEBA-based epoxy resins are described. Furthermore, the same skin testings and specific immunoglobulin ( $\mathrm{Ig}) \mathrm{E}$ determinations that were performed for these two patients were also performed for five other patients who had occupationally been exposed to chemicals in the epoxy resin system and who had developed respiratory symptoms suspected to be related with that work. However, no specific immediate allergy to epoxy resin chemicals was detected.

\section{Patients and methods}

Patients. Two patients who had immediate and delayed allergy to DGEBA-based epoxy resins are presented. These two patients have earlier been described as patients 32 and 34 in the report of Jolanki et al (5). Furthermore, data on investigations used to detect immediate allergy to epoxy resins and phthalic anhydrides in five patients with suspicion of work-related respiratory symptoms in a factory manufacturing insulators from epoxy resins are given (16). Patients $5-7$ in the 
present study correspond to the same patient numbers in a previous report (16).

Epoxy resins and phthalic anhydrides. The following epoxy resins were used for the prick and patch tests and specific IgE determinations: Epikote 827 (Shell Chemie, The Netherlands), Araldit CY 184 (CibaGeigy, Switzerland), Lekutherm X 100 (Bayer AG, Germany), Lekutherm X 287 (Bayer AG, Germany), and diglycidyl ether of bisphenol A (DGEBA) (ie, DGEBA-based epoxy resin of molecular weight 340) purified from Epikote 827.

Epikote 827 is the DGEBA-based epoxy resin from which our standard patch test epoxy resin preparation was made. Lekutherm X 287 is a mixture of DGEBA and diglycidyl aniline type epoxy resins, whereas Araldit CY 184 and Lekutherm X 100 are cycloaliphatic epoxy resins based on a monomer of molecular weight 284 [ie, diglycidyl ester of hexahydrophthalic acid (DGEHHPA)] (16).

For more-detailed information on the purity of the epoxy resins, the amounts of the allergens DGEBA, DGEHHPA, and nine reactive diluents (17) were determined with gas chromatography and high-performance liquid chromatography $(18-20)$. The results are given in table 1 .

The following phthalic anhydrides were used to make conjugates with human serum albumin (HSA): methyl tetrahydrophthalic anhydride (MTHPA) (FW750, Hitachi Chemical Co, Ltd, Japan), methyl hexahydrophthalic anhydride (MHHPA) (Lekutherm M, Bayer AG), hexahydrophthalic acid (HHPA) (HT 907, Ciba-Geigy), and phthalic anhydride (PA) (Neste Chemicals, Finland). Bronchial provocation tests (MTHPA) and patch tests (MTHPA, MHHPA, and PA) were performed with the aforementioned phthalic anhydrides or the patients' own products.

Preparation of hapten conjugates of human serum albumin. Stock solutions of epoxy resin conjugates and anhydride conjugates of HSA were prepared as fol- lows. The conjugation between haptens (ie, epoxy resins and phthalic anhydrides) and HSA was carried out essentially as described by Howe et al in 1983 (21). In brief, $400 \mathrm{mg}$ of the hapten dissolved in $2 \mathrm{ml}$ of acetone was stirred into $40 \mathrm{ml}$ of a $1 \%$ [weight/volume (w/v)] solution of HSA (Fraction V, Sigma Chemical Company, St Louis, Missouri, United States) in $9 \%$ sodium hydrogen carbonate for $1 \mathrm{~h}$ in an ice bath. After filtration through filter paper (Munktell OOH, Grycksbo Pappersbruk AB, Sweden), the hapten-HSA conjugate was concentrated to a $2 \%$ HSA solution as follows: the buffer was changed to Coca solution (0.5\% sodium chloride, $0.3 \%$ sodium hydrogen carbonate, $0.4 \%$ phenol) or to $0.1 \mathrm{M}$ potassium phosphate buffer, $\mathrm{pH} 7.4$, containing sodium azide ( $3 \mathrm{mmol} / \mathrm{l}$ ) for the stock solutions of the prick tests and specific IgE determinations, respectively, by ultrafiltration through a Diaflo YM 30 membrane (Amicon Corporation, Danvers, Massachusetts, United States; cutoff 30000 daltons). Control HSA stock solutions were prepared in the same manner but without hapten.

For the prick test solutions the hapten-HSA conjugate and control HSA stock solutions were diluted to a concentration of $1 \%(w / v)$ of HSA with Coca solution containing $50 \%$ glycerol. The solutions were filtered through a sterile $0.22 \mu \mathrm{m}$ Millex-GV filter (Millipore, France) into sterile vials and stored at $5^{\circ} \mathrm{C}$.

DGEBA (ie, DGEBA-based epoxy resin of molecular weight 340) was purified from Epikote 827 containing $89 \%$ DGEBA (table 1) with thin-layer chromatography as described by Fregert \& Trulsson (22). Briefly, an aliquot of a $1 \%$ solution of the epoxy resin in acetone was spread as a line on a silica thin-layer plate (DC-Alufolien Kieselgel 60, F 254, Merck, Germany) $2 \mathrm{~cm}$ from the bottom. The plate was eluted with a mixture of chloroform and acetonitrile $90 / 10$ [volume/volume $(\mathrm{v} / \mathrm{v})$ ], visualized under ultraviolet light, and the DGEBA band was scraped with a spatula. The scraped material was dissolved in acetone, spread on another thin-layer plate, eluted, visualized, scraped, and dissolved as already described. All the dissolved material (less than $400 \mathrm{mg}$ ) was used as the

Table 1. Amounts of epoxy resin monomers and nine reactive diluents in epoxy resins used for the skin tests and specific IgE determinations. (DGEBA = diglycidyl ether of bisphenol $\mathrm{A}$, DGEHHPA = diglycidyl ester of hexahydrophthalic acid)

\begin{tabular}{|c|c|c|c|c|}
\hline \multirow{2}{*}{ Substance } & \multicolumn{4}{|c|}{ Percentage present } \\
\hline & Epikote 827 & Araldit CY 184 & Lekutherm X 100 & Lekutherm $\times 287^{a}$ \\
\hline \multicolumn{5}{|l|}{ Epoxy resin monomers } \\
\hline $\begin{array}{l}\text { DGEBA of molecular weight } 340^{\mathrm{b}} \\
\text { DGEHHPA of molecular weight } 284^{\mathrm{c}}\end{array}$ & 89 & $\begin{array}{r}<0.002 \\
\quad \approx 50\end{array}$ & $\begin{array}{r}0.5 \\
\approx 70\end{array}$ & $\frac{43}{-}$ \\
\hline \multicolumn{5}{|l|}{ Reactive diluents ${ }^{c}$} \\
\hline $\begin{array}{l}\text { 1,4-Butanediol diglycidyl ether } \\
\text { Glycidyl ethers of aliphatic alcohols } \\
\text { Phenyl glycidyl ether }\end{array}$ & $\overline{-}$ & $\frac{0.4}{-}$ & $0 . \overline{02}$ & $\underline{0 . \overline{06}}$ \\
\hline
\end{tabular}


hapien for the preparation of the HSA conjugates of DGEBA. A control sample was scraped from the plate above the DGEBA band.

Skin tests. Skin tests to 20 common environmental allergens, including epithelia, pollens, and dust mite (Allergologisk Laboratorium A/S, Denmark) were performed with the standard prick test technique of Aas $\&$ Belin (23). Histamine hydrochloride $(10 \mathrm{mg} / \mathrm{ml})$ was used as a positive control, and a test solution prepared as antigen solution without an antigen served as a negative control (23). The positivity of the prick test results was evaluated according to commonly accepted rules $(23,24)$. The same technique and corresponding control solutions were used when the prick tests were performed with hapten-HSA conjugates.

The patch tests were done and scored as previously described $(5,25)$ with an occlusion time of $48 \mathrm{~h}$. The European standard series (Chemotechnique Diagnostics AB, Sweden), a series of plastics and glues (Chemotechnique Diagnostics AB and Trolab, Hermal-Chemie Kurt Herrmann, Germany) (26), the (meth)acrylate series (Chemotechnique Diagnostics
$A B)$, and a series of nine epoxy reactive diluents (17) were used for the patch testing. Epoxy resins and phthalic anhydrides were tested at $1 \%$ [weight/weight $(\mathrm{w} / \mathrm{w})]$ in petrolatum; other substances brought in by the patients ("own substances") were tested at 1$10 \%(\mathrm{w} / \mathrm{w})$ in petrolatum.

Specific immunoglobulin E determinations to epoxy resins and phthalic anhydrides. Hapten-HSA conjugate solutions and control solutions at a concentration of $2 \%$ HSA were coupled to filter paper discs (Munktell $\mathrm{OOH}$ ) activated with cyanogen bromide, $100 \mu \mathrm{l}$ of conjugate being used per disc, as described by Ceska $\&$ Lundkvist (27). The discs and Phadezym RAST reagents (Pharmacia Diagnostics, Sweden) were used in the specific IgE determinations and the inhibition experiments. The quantity of specific IgE bound to a disc is given as the ratio of absorbances at $420 \mathrm{~nm}$ of the hapten-HSA disc to the HSA-control disc. A ratio of three or more was defined as positive (table 2) provided that the absorbance of the hapten-HSA disc was half that of the reference (RAST reference D; 0.35 PRU/ml, Pharmacia Diagnostics).

Table 2. Characteristics of patients 1 and 2 and the results of their skin tests and specific immunoglobulin (Ig) E determinations. (DGEBA = diglycidyl ether of bisphenol A, PA = phthalic anhydride, HHPA = hexahydrophthalic anhydride, MHHPA = methyl hexahydrophthalic anhydride, MTHPA = methyl tetrahydrophthalic anhydride, $p s=$ pseudopodia)

\begin{tabular}{|c|c|c|c|}
\hline & & Patient 1 & Patient 2 \\
\hline \multicolumn{4}{|l|}{ Characteristics } \\
\hline $\begin{array}{l}\text { Age } \\
\text { Gender } \\
\text { Work }\end{array}$ & & $\begin{array}{l}56 \text { years } \\
\text { Female } \\
\text { Cleaning }\end{array}$ & $\begin{array}{l}48 \text { years } \\
\text { Female } \\
\text { Electrical insulating and } \\
\text { connecting }\end{array}$ \\
\hline $\begin{array}{l}\text { Smoking } \\
\text { Dermatitis (since) } \\
\text { Asthma (since) } \\
\text { Diagnosis } \\
\text { Exposure (main) }\end{array}$ & & $\begin{array}{l}\text { Ex-smoker } \\
1982 \\
1987 \\
1988 \\
\text { DGEBA-based epoxy } \\
\text { resin, polyamine and } \\
\text { MTHPA hardeners }\end{array}$ & $\begin{array}{l}\text { Nonsmoker } \\
1962 \\
1986 \\
1988 \\
\text { DGEBA-based epoxy } \\
\text { resin, polyamine } \\
\text { hardener }\end{array}$ \\
\hline \multicolumn{4}{|l|}{ Patch tests } \\
\hline $\begin{array}{l}\text { Epikote } 827 \\
\text { (= standard epoxy resin) } \\
\text { Araldit CY } 184 \\
\text { Lekutherm X } 100 \\
\text { MHHPA and HHPA }\end{array}$ & $\begin{array}{l}1 \% \text { in petrolatum } \\
1 \% \text { in petrolatum } \\
1 \% \text { in petrolatum } \\
1 \% \text { in petrolatum }\end{array}$ & $\begin{array}{l}- \\
-\end{array}$ & $\begin{array}{l}- \\
- \\
-\end{array}$ \\
\hline \multicolumn{4}{|l|}{ Prick tests } \\
\hline $\begin{array}{l}\text { Standard series } \\
\text { Histamine }(10 \mathrm{mg} / \mathrm{ml}) \\
\text { Epikote } 827 \\
\text { MTHPA } \\
\text { MHHPA, HHPA and PA }\end{array}$ & & $\begin{array}{l}- \\
5 \mathrm{~mm} \\
5 \mathrm{~mm} \text { (positive) } \\
7 \mathrm{~mm}+\mathrm{ps} \text { (positive) } \\
-\end{array}$ & $\begin{array}{l}- \\
6 \mathrm{~mm} \\
8 \mathrm{~mm} \text { (positive) } \\
- \\
-\end{array}$ \\
\hline \multicolumn{2}{|l|}{ Specific IgE determinations } & $\begin{array}{l}\text { Absorbance } \\
420 \mathrm{~nm} \text { Ratio }\end{array}$ & $\begin{array}{l}\text { Absorbance } \\
420 \mathrm{~nm} \quad \text { Ratio }\end{array}$ \\
\hline $\begin{array}{l}\text { HSA } \\
\text { Epikote } 827 \\
\text { DGEBA (from Epikote } 827 \text { ) } \\
\text { Araldit CY } 184 \\
\text { Lekutherm } \times 100 \\
\text { Lekutherm X } 287 \\
\text { MTHPA } \\
\text { MHHPA } \\
\text { PA }\end{array}$ & & $\begin{array}{ll}0.023 & \\
0.225 & 9.8 \text { positive } \\
0.091 & 4.0 \text { positive } \\
0.019 & 0.8 \\
0.028 & 1.2 \\
0.160 & 7.9 \text { positive } \\
0.131 & 5.7 \text { positive } \\
0.114 & 5.0 \text { positive } \\
0.038 & 1.7\end{array}$ & $\begin{array}{ll}0.016 & \\
0.547 & 34 \text { positive } \\
0.229 & 14 \text { positive } \\
0.016 & 1.0 \\
0.030 & 1.9 \\
0.340 & 21 \text { positive } \\
0.016 & 1.0 \\
0.022 & 1.4 \\
0.015 & 0.9\end{array}$ \\
\hline
\end{tabular}


Inhibition tests. Inhibition of the specific IgE determinations was carried out as described by Yman et al (28). Briefly, a dilution series (1:1 v/v, 1:10, 1:100, etc) was prepared from the stock hapten-HSA conjugate solution with $0.1 \mathrm{M}$ potassium phosphate buffer, $\mathrm{pH} 7.0$, containing sodium azide $(3 \mathrm{mmol} / \mathrm{l})$. Fifty microliters of serum and $20 \mu \mathrm{l}$ of each hapten-HSA conjugate dilution were added to a polystyrene tube, and the tubes were incubated for $3 \mathrm{~h}$ at room temperature. A respective hapten-HSA disc was added, and the assay was continued using the standard Phadezym RAST technique.

Lung function and provocation tests. The spirograms were recorded with a Medikro 101 spirometer (Medikro Oy, Finland). Rimiterol hydrobromide $(0.2 \mathrm{mg})$ (three puffs) was used in the bronchodilation test. An increase of at least $15 \%$ and $150 \mathrm{ml}$ in the forced expiratory volume in $1 \mathrm{~s}\left(\mathrm{FEV}_{1.0}\right)$ was regarded as significant. Bronchial hyperreactivity was assessed with the histamine challenge test described by Laitinen (29) using an automatic dosimetric inhaler. Bronchial provocation tests were carried out in a challenge chamber according to the method of Newman Taylor \& Davies (30). Challenges with chemicals, but not with epoxy resins, were performed. A polyol was used as a placebo.

\section{Results and case reports}

The main characteristics and skin test results of the two patients who had asthma are summarized in table 2. Twenty unexposed controls and five other exposed patients (ie, workers from an insulator factory) (table 3) had negative prick tests and specific. IgE determinations to the epoxy resins and phthalic anhydrides.

Patient 1. Patient 1 had been working as a cleaner since 1980 in a factory manufacturing ski poles and other sports articles made of DGEBA-based epoxy resins and polyester resins. The epoxy hardener was earlier a polyamine compound, and since 1985 it has been MTHPA. The patient had no own or family history of atopy. In 1982 she experienced the first symptoms of dermatitis on the back of her hands and lower arms. Since 1984 she had had dyspnea that was aggravated by exercise; since 1987 she had also had asthmatic symptoms at work. Concomitantly her dermatitis had spread to her forehead and neck. She had had epoxy resin exposure via both respiratory and skin contact because her duty was to clean rooms containing mucil plastic dust. She worked without protective gloves until she started to develop skin symptoms.

When examined in February 1988 her physical status was normal except for the wheezing rales from her lungs. The diurnal variation in peak expiratory flow was $8 \%$. After proper asthma treatment the symptoms disappeared, and no rales were heard. She had a mild obstruction in her spirometry \{FEV \% [ $(100 \times$ $\mathrm{FEV}_{1.0}$ )/ forced vital capacity] 70-78\}, but the bronchodilatation test was negative. In February of 1988 she had moderate bronchial hyperreactivity which had disappeared in April after she had been away from work and used asthma medication. She had no straininduced asthma, and her chest radiograph was normal. The bronchial provocation tests with the placebo, poly-

Table 3. Characteristics and test results of five persons exposed to epoxy resin and phthalic anhydride in an insulator factory and suffering from respiratory symptoms. (DGEBA = diglycidyl ether of bisphenol A, Ig = immunoglobulin, MHHPA=methyl hexahydrophthalic anhydride, HHPA = hexahydrophthalic anhydride, MTHPA = methyl tetrahydrophthalic anhydride)

\begin{tabular}{|c|c|c|c|c|c|}
\hline & Patient 3 & Patient 4 & Patient 5 & Patient 6 & Patient 7 \\
\hline \multicolumn{6}{|l|}{ Characteristics } \\
\hline $\begin{array}{l}\text { Age } \\
\text { Gender } \\
\text { Work }\end{array}$ & $\begin{array}{l}42 \text { years } \\
\text { Male } \\
\text { Casting }\end{array}$ & $\begin{array}{l}47 \text { years } \\
\text { Female } \\
\text { Casting, coil } \\
\text { winding }\end{array}$ & $\begin{array}{l}49 \text { years } \\
\text { Male } \\
\text { Repair }\end{array}$ & $\begin{array}{l}44 \text { years } \\
\text { Female } \\
\text { Casting }\end{array}$ & $\begin{array}{l}44 \text { years } \\
\text { Female } \\
\text { Casting }\end{array}$ \\
\hline $\begin{array}{l}\text { Total duration of expc } \\
\text { of prick tests and spe } \\
\text { determinations } \\
\text { Symptoms }\end{array}$ & $\begin{array}{l}19 \text { years } \\
\text { Rhinitis, } \\
\text { dermatitis }\end{array}$ & $\begin{array}{l}9 \text { years } \\
\text { Rhinitis }\end{array}$ & $\begin{array}{l}13 \text { years } \\
\text { Rhinitis, } \\
\text { dermatitis }\end{array}$ & $\begin{array}{l}5 \text { years } \\
\text { Rhinitis, } \\
\text { dermatitis }\end{array}$ & $\begin{array}{l}5 \text { years } \\
\text { Rhinitis, } \\
\text { dermatitis }\end{array}$ \\
\hline \multicolumn{6}{|c|}{ Patch tests, $1 \%$ in petrolatum } \\
\hline $\begin{array}{l}\text { Standard epoxy resin } \\
\text { Araldit CY } 184 \\
\text { Lekutherm X } 100 \\
\text { Lekutherm X } 287 \\
\text { MHHPA, HHPA, PA }\end{array}$ & $\begin{array}{l}- \\
- \\
- \\
- \\
-\end{array}$ & $\begin{array}{l}\text { Not done } \\
\text { Not done } \\
\text { Not done } \\
\text { Not done } \\
\text { Not done }\end{array}$ & $\begin{array}{l}- \\
2+ \\
2+ \\
+ \\
-\end{array}$ & $\begin{array}{l}- \\
2+ \\
+? \\
- \\
-\end{array}$ & $\begin{array}{l}- \\
2+ \\
2+ \\
2+ \\
-\end{array}$ \\
\hline \multicolumn{6}{|c|}{$\begin{array}{l}\text { Prick tests and specific } \lg \mathrm{E} \\
\text { determinations }\end{array}$} \\
\hline $\begin{array}{l}\text { Epikote } 827 \\
\text { DGEBA } \\
\text { Araldit CY } 184 \\
\text { Lekutherm X } 100 \\
\text { Lekutherm X } 287 \\
\text { MTHPA, MHHPA, PA }\end{array}$ & $\begin{array}{l}- \\
- \\
- \\
- \\
-\end{array}$ & $\begin{array}{l}- \\
- \\
- \\
- \\
-\end{array}$ & $\begin{array}{l}- \\
- \\
- \\
- \\
-\end{array}$ & $\begin{array}{l}- \\
- \\
- \\
- \\
-\end{array}$ & $\begin{array}{l}- \\
- \\
- \\
- \\
-\end{array}$ \\
\hline
\end{tabular}


amine hardener, and cold MTHPA $\left(0.2 \mathrm{mg} / \mathrm{m}^{3}\right)$ were negative. When MTHPA was heated to the same temperature $\left(100^{\circ} \mathrm{C}\right)$ as was used at the workplace, the MTHPA concentration in the chamber air was 7 $\mathrm{mg} / \mathrm{m}^{3}$ during the provocation test $(30 \mathrm{~min})$, and wheezing rales were induced after $6 \mathrm{~h}$, but the peak expiratory flow decreased only $10 \%$. No challenge test with DGEBA-based epoxy resins or the surveillance of peak expiratory flow at the workplace was carried out because of the patient's allergic contact dermatitis from the DGEBA-based epoxy resins. On patch testing she reacted with a $2+$ allergic reaction to the standard epoxy resin. Her other patch tests were negative (table 2).

The prick tests with Epikote 827-HSA and MTHPAHSA were positive (table 2) as were also the specific IgE determinations to DGEBA, two epoxy resins (Epikote 827 and Lekutherm X 287) containing DGEBA, and to two anhydrides (MTHPA and MHHPA) (table 2).

The diagnosis of probable occupational asthma was based on history, the sensitization to DGEBA-based epoxy resins and MTHPA verified by prick tests and specific IgE determinations and the disappearance of hyperreactivity after an unexposed period. The reaction with short MTHPA challenge was not significant. When the patient was seen after six months without exposure, she used asthma medication, but had fewer symptoms, and her spirometry was normal.

Patient 2. Patient 2 worked as a connector in a factory manufacturing electronic devices. She was admitted to examination because of asthmatic symptoms. She had worked in the electrical industry in 1962-1963, 1963-1966, and since 1969 in her present job. She had had mild atopic dermatitis but had not suffered from any respiratory symptoms in her youth. During 1962-1963 she developed severe dermatitis on her face, hands, and lower arms when she was exposed to epoxy resins while working as an insulator. She was asked to change her job, but no patch tests were performed. It seems evident that at that time she had been sensitized to epoxy resins, to which she was commonly exposed in that factory. Since then she has experienced pruritic hand and face dermatitis after being exposed to epoxy glues. In her present work she was handling electrical components containing epoxy glue which was still partly uncured. The epoxy glue contained DGEBA-based epoxy resins and aliphatic polyamines as hardeners. She had also probably been exposed to airborne epoxy resin because plenty of uncured epoxy resin was handled close to her worksite. Since the late 1970s she had been on sick leave several times because of her severe hand and face dermatitis. In 1986 she began to develop asthmatic symptoms, which worsened during the work shifts. She was also exposed to cyanoacrylate and colophony in her work.

The prick test with Epikote 827-HSA was positive, but with PA-HSA it was negative (table 2). The specific
IgE determinations to DGEBA and the two epoxy resins containing DGEBA were strongly positive, but to phthalic anhydrides the specific IgE determinations were negative. In the standard patch test series cobalt chloride, $1 \%$ in petrolatum, gave a $2+$ reaction, and the standard epoxy resin gave a strong vesicular $(3+)$ reaction. Three epoxy acrylates were positive in the (meth)acrylate series (see reference 25) (ie, BIS-GMA [2,2-bis(4-(2-hydroxy-3-methacryloxypropoxy)phenyl) propane], BIS-EMA [2,2-bis(4-(2-methacryloxyethoxy) phenyl)propane], and BIS-GA [2,2-bis(4-(2-hydroxy3-acryloxypropoxy)phenyl)propane]. BIS-GMA gave a $3+$ reaction, and the other two produced a $2+$ reaction. A fourth epoxy acrylate, BIS-MA [2,2,-bis(4(methacryloxy)phenyl)propane], was negative, as were the other 25 (meth)acrylates tested (25). The series of plastics and glues, including cyanoacrylate, was negative.

The diurnal variation in peak expiratory flow was $7 \%(365-340 \mathrm{l} / \mathrm{min})$. The spirometric values were normal. The patient had mild bronchial hyperreactivity. The bronchial provocation tests with the placebo were negative, as well as the challenge with colophony and a cyanoacrylate glue. Challenge tests with epoxy compounds or surveillance of peak expiratory flow at the workplace was not carried out because of the severe allergic contact dermatitis from exposure to DGEBA-based epoxy resins. After six months without exposure, the asthmatic symptoms had decreased, and the patient had no nonspecific bronchial hyperreactivity in the histamine challenge test.

The diagnosis of probable occupational asthma was based on the history, the sensitization to DGEBAbased epoxy resins verified by the prick tests and specific IgE determinations, and the disappearance of hyperreactivity after a period of nonexposure.

Inhibition tests. Experiments to inhibit specific IgE determinations were carried out with serum from both patients to prove the specificity of the determinations for the DGEBA-based epoxy resin Epikote-827. The results showed that the specific IgE determinations could be inhibited nearly completely with HSA conjugate of Epikote 827 (figure 1). When the MTHPAHSA conjugate was used as the inhibitor, no specific inhibition could be demonstrated.

Patients from an insulator factory. Eighty patients were working in a department manufacturing insulators from the epoxy resins Araldit CY 184, Lekutherm $X 100$, and Lekutherm X 287 using phthalic anhydrides (PA, HHPA, MHHPA) as hardeners. Twenty-one of the 80 workers had skin and/or respiratory symptoms, 14 having only skin symptoms, three only respiratory symptoms, and four both types of symptoms. Twelve workers (of 18 with skin symptoms) were found to have allergic contact dermatitis from cycloaliphatic epoxy resins. The patch test results have been published elsewhere (16). 


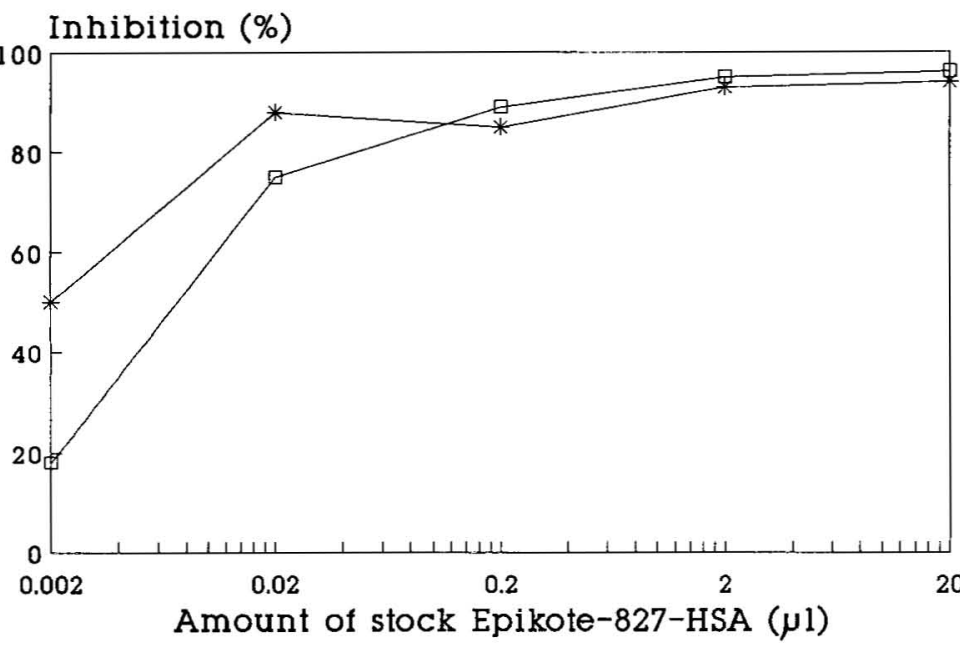

$\rightarrow$ Patient $1 \rightarrow$ Patient 2
Figure 1. Inhibition in the specific immunoglobulin $\mathrm{E}$ determinations with an epoxy resin based on diglycidyl ether of bisphenol A (Epikote 827).
Five patients who complained of respiratory symptoms which could have been due to the epoxy resins or their hardeners were studied with the same prick tests and specific IgE determinations as the two patients that have already been presented (ie, DGEBA, four other epoxy resins, and three phthalic anhydrides). Four of these patients had skin symptoms and were patch tested. Three of them (patients 5-7) had allergic contact dermatitis from the epoxy resins used in the factory.

The characteristics of the patients and test results are given in table 3 . The prick tests and specific $\operatorname{IgE}$ determinations to the epoxy resins and phthalic anhydrides were negative in all cases and therefore indicated that none of the patients had a specific immediate allergy to the chemicals.

\section{Discussion}

Low-molecular weight chemicals act as haptens in type IV (delayed) allergic reactions causing allergic contact dermatitis. Proteins, on the other hand, have been regarded as the inducers of IgE production and type I (immediate) allergic reactions. More recent clinical observations indicate that chemicals with a molecular weight usually below 1000 may also induce immediate allergic symptoms $(31,32)$. This phenomenon has largely been neglected in the dermatologic literature because type I allergic reactions often affect the respiratory tract, and in many countries dermatologists do not regularly perform type I allergy investigations (23). With the increase in awareness of contact urticaria (33), dermatologists are now paying more attention to type I allergy. Immediate reactions should be remembered as it has become evident that type I and type IV allergic reactions to the same compounds coexist more often than was previously believed (24). The present report indicates that DGEBA-based epoxy resins can be added to the list of substances able to cause both of these types of allergies.

Hapten-HSA conjugates for the prick test and specific IgE determinations have to be adapted to each individual hapten (31). The allergen formed in vivo is not known, and therefore the procedure for preparing hapten-protein conjugates is currently largely on the "trial and error" level. Several variables (such as substance concentration and $\mathrm{pH}$ ) may influence the preparation of conjugates (31). By using the method of Howe et al (21), we were able to get reproducible hapten-HSA conjugates with DGEBA-based epoxy resins and phthalic anhydrides. Prick tests, specific IgE determinations, and the appropriate controls indicated that our patients had IgE-mediated allergy from the chemicals in the epoxy resin system. Earlier, specific IgE antibodies have been demonstrated for, for example, the following low-molecular weight chemicals: isocyanates, reactive textile dyes, acid anhydrides, platinum group of metal salts, chloramine-T, and ethylene oxide (31).

According to the history, exposure, and sensitization to DGEBA-based epoxy resins (which was verified with prick tests and specific IgE determinations) and because the bronchial hyperreactivity disappeared after the unexposed period, it was feasible to conclude that both patients had occupational asthma due to exposure to DGEBA-based epoxy resins. Unfortunately, we were unable to perform bronchial provocation tests with DGEBA-based epoxy resins for ethical reasons. Once earlier, an epoxy resin bronchial provocation test was performed in the exposure chamber with an asthmatic patient who had allergic contact dermatitis from exposure to DGEBA-based epoxy resins, and the patient developed extensive erythrodermic dermatitis. This reaction was probably due to airborne contact with the resin but may also have reflected systemic contact dermatitis (34). From the point of insurance 
medicine the diagnostic tests were considered sufficient, and both patients were compensated for both occupational asthma and occupational allergic contact dermatitis. Neither of the patients could continue their previous work and had to retire. The first patient experienced dyspnea in 1984 before MTHPA was taken into use as a hardener. Therefore the patient had probably been sensitized first to DGEBA-based epoxy resins and then to MTHPA.

Bronchial asthma (12), rhinitis (13), and urticaria $(12,14)$ from exposure to epoxy resins have earlier been reported. To the best of our knowledge, tests to demonstrate that these symptoms could be IgE-mediated have not been performed earlier. The type I allergy of our patients appeared as respiratory symptoms and pruritus. Both patients complained of immediate pruritus from epoxy resin. It is evident that this occurrence was a sign of contact urticaria although hives were not present. IgE-mediated pruritus without hives has been reported to result from the use of latex gloves (35). It is possible that sensitization had occurred through skin contact. Our observations of the patient group from an insulator factory indicate that type I allergy from epoxy resins is possibly rare although the patients have strong exposure to epoxy resins. It remains to be seen whether more cases with type I allergy from epoxy resins of the DGEBA or nonDGEBA type (eg, cycloaliphatic epoxy resins) will be detected when specific IgE determinations and prick tests for epoxy resins are used to investigate patients who are exposed to epoxy resins and have respiratory or (contact) urticaria symptoms. Using HSA conjugate of cycloaliphatic epoxy resins, we have had no positive prick tests or specific IgE determinations so far, and therefore we cannot be certain whether HSA conjugates of cycloaliphatic epoxy resins are usable in the verification of immediate allergy to cycloaliphatic epoxy resins. No cross-reactivity was observed between the specific IgE determinations for DGEBA-based epoxy resins and for cycloaliphatic epoxy resins, as observed between phthalic anhydrides. Positive specific IgE determinations to DGEBA (ie, purified DGEBAbased epoxy resin of molecular weight 340 ) indicated that the DGEBA was the specific allergen in the two asthma patients. Absorbance at $420 \mathrm{~nm}$ of the DGEBA-HSA disc was less than that of the DGEBAbased epoxy resin (Epikote 827)-HSA disc, probably because a smaller amount of hapten was used for the HSA conjugates of DGEBA than for the HSA conjugates of the DGEBA-based epoxy resin. Specific IgE determinations to Lekutherm X 287 were positive due to the large amount of DGEBA (table 1).

The patch tests and clinical data confirmed that both patients had allergic contact dermatitis from exposure to DGEBA-based epoxy resins. Patient 2 also had positive patch test reactions to epoxy acrylates (BIS-GMA, BIS-EMA, and BIS-GA). She was the only one of six patients (with allergic contact dermatitis due to DGEBA-based epoxy resins and tested with BIS-GMA) who had concomitant allergic reactions to DGEBAbased epoxy resins and BIS-GMA (5). This finding may indicate cross-reactivity between the test substances. Other possibilities for the concomitant positive reactions with the standard epoxy resin and the epoxy acrylates in patch testing reactions have recently been discussed elsewhere $(25,36)$.

Patient 2 was also positive to cobalt chloride in the patch test. In the 1960s she had been exposed to polyester resins in which cobalt was used as an accelerator. Thus she had probably become occupationally sensitized to cobalt. Earlier we also diagnosed occupational contact allergy to cobalt in a patient from the same workplace. Recently we had a patient who had become sensitized to cobalt from exposure to polyester laminating resin in boat building (unpublished).

\section{Acknowledgments}

The authors are grateful to M-L Henriks-Eckerman, Turku Regional Institute of Occupational Health, Tur$\mathrm{ku}$, Finland, for performing the high-performance liquid chromatographic and gas chromatographic analyses of the epoxy resins and to Ms P Pfäffli, Institute of Occupational Health, Helsinki, Finland, for performing the gas chromatographic analyses of MTHPA during the provocation challenges.

\section{References}

1. Thorgeirsson A, Fregert S. Allergenicity of epoxy resins in the guinea pig. Acta Derm Venerol (Stockh) 1977; $57: 253-6$.

2. Thorgeirsson A, Fregert S, Ramnäs O. Sensitization capacity of epoxy resin oligomers in the guinea pig. Acta Derm Venerol (Stockh) 1978;58(1):17-21.

3. Jolanki R, Estlander T, Kanerva L. Occupational contact dermatitis and contact urticaria caused by epoxy resins. Acta Derm Venerol Suppl (Stockh) 1987;134:90-4.

4. Kanerva L, Estlander T, Jolanki R. Occupational skin disease in Finland: an analysis of 10 years of statistics from an occupational dermatology clinic. Int Arch Occup Environ Health 1988;60:89-94.

5. Jolanki R, Kanerva L, Estlander T, Tarvainen K, Keskinen $\mathrm{H}$, Henriks-Eckerman M-L. Occupational dermatoses from epoxy resin compounds. Contact Dermatitis $1990 ; 23: 172-83$.

6. Thorgeirsson A. Sensitization capacity of epoxy resin hardeners in the guinea pig. Acta Derm Venerol (Stockh) 1978;58:332-6.

7. Fregert $\mathrm{S}$. Contact dermatitis from epoxy resin systems In: Maibach HI, ed. Occupational and industrial dermatology. 2nd ed. Chicago, IL: Year Book Medical Publishers Inc, 1987:341-5.

8. Göransson K. Allergic contact dermatitis to an epoxy hardener: dodecenyl-succinic anhydride. Contact Dermatitis 1977;3:277-8.

9. Bernstein IL, Bernstein DI. Respiratory allergy to synthetic resins. In: Pepys J, ed. Clinics in immunology and allergy: occupational respiratory allergy; vol 4. Philadelphia, PA: WB Saunders Company, 1984:83-101.

10. Newman Taylor AJ, Venables KM. Clinical and epidemiological methods in investigating occupational asthma. In: Pepys J, ed. Clinics in immunology and allergy: occupational respiratory allergy; vol 4. Philadelphia, PA: WB Saunders Company, 1984: 3-17.

11. Fisher AA. Contact Dermatitis. 3rd ed. Philadelphia, PA: Lea \& Febiger, 1986. 
12. Woyton A, Wasik F, Blizanowska A. An uncommon anaphylactic and eczematous reaction after contact with epoxide resins [in Polish]. Przegl Dermatol 1974;61: $303-8$.

13. Romaguera C, Grimalt F, Vilaplana J. Dermatitis de contacto profesional y por resina epox [Occupational contact dermatitis from epoxy resin]. Med Segur Trab 1984;31:63-4.

14. Suhonen R. Epoxy-dermatitis in a ski-stick factory. Contact Dermatitis 1983;9:131-3.

15. Keskinen H, Nordman H, Tupasela O, Vaheri E, Pfäffli $P$, Sarjanen M. Methyl hexahydrophthalic anhydride (MHHPA) induced asthma and rhinitis. N Engl Reg Allergy Proc 1988;9:397.

16. Jolanki R, Sysilampi M-L, Kanerva L, Estlander T. Contact allergy to cycloaliphatic epoxy resins. In: Frosch PJ, Dooms-Goossens A, Lachapelle J-M, Rycroft RJG, Scheper RJ, ed. Current topics in contact dermatitis. Berlin, Heidelberg: Springer-Verlag, 1989:360—7.

17. Jolanki R, Estlander T, Kanerva L. Contact allergy to an epoxy reactive diluent: 1.4-butanediol diglycidyl ether. Contact Dermatitis 1987;16:87-92.

18. Henriks-Eckerman M-L. Gas chromatographic determination of the oligomer of molecular weight 340 in epoxy resins. J Chromatogr 1982;244:378-80

19. Henriks-Eckerman M-L, Laijoki T. Epoksituotteiden sisältämät glysidyylieetterit [Glycidyl ethers in epoxy resin products]. Työterveyslaitoksen tutkimuksia 1986; 4:41-6, 70. (English summary.)

20. Jolanki R, Estlander T, Henriks-Eckerman M-L, Kanerva $L$, Stjernvall $T$. Skin protection and sensitizing epoxy compounds in electron microscopy laboratories. In: Mansdorf SZ, Sager R, Nielsen AP, ed. Performance of protective clothing: second symposium. Philadelphia, PA: American Society for Testing and Materials 1988: 389-395. (ASTM STP 989.)

21. Howe W, Venables KM, Topping MD, Dally MB, Hawkins R. Law JS, Newman Taylor AJ. Tetrachlorophthalic anhydride asthma: evidence for specific IgE antibody. J Allergy Clin Immunol 1983;71:5-11.

22. Fregert S, Trulsson L. Simple methods for demonstration of epoxy resins of bisphenol A type. Contact Dermatitis 1978;4:69-72.

23. Aas K, Belin L. Standardization of diagnostic work in allergy. Int Arch Allergy Appl Immunol 1973;45:57-60.

24. Kanerva L, Estlander T, Jolanki R. Skin testing for im- mediate hypersensitivity in occupational allergology. In: Menné T, Maibach HI, ed. Exogenous Dermatoses: environmental dermatitis. Boca Raton, FL: CRC Press Inc, 1990:103-126.

25. Kanerva L, Estlander T, Jolanki R. Allergic contact dermatitis from dental composite resins due to aromatic epoxy acrylates and aliphatic acrylates. Contact Dermatitis 1989;20:201-11.

26. Kanerva L, Jolanki R, Estlander T. Allergic contact dermatitis from epoxy resin hardeners. Am J Contact Dermatitis (in press).

27. Ceska M, Lundkvist U. A new and simple radioimmunoassay method for the determination of IgE. Immunochemistry 1972;9:1021 - 30.

28. Yman L, Ponterius G, Brandt R. RAST-based allergen assay methods. Dev Biol Stand 1975;29: 151-65.

29. Laitinen LA. Histamine and metacholine challenge in the testing of bronchial reactivity. Scand J Respir Dis Suppl 1974;86:1-48.

30. Newman Taylor AJ, Davies RJ. Inhalation challenge testing. In: Weil H, Turner-Warwick M, ed. Occupational lung diseases. New York, NY: Marcel Dekker Inc, 1981:143-67.

31. Wass U. Studies on IgE antibodies induced by lowmolecular-weight chemicals [Doctoral dissertation]. Göteborg (Sweden): University of Göteborg, 1989.

32. Bernstein DI, Zeiss CR: Guidelines for preparation and characterization of chemical-protein conjugate antigens: report of the subcommittee on preparation and characterization of low molecular weight antigens. J Allergy Clin Immunol 1989;84:820-2.

33. Lahti A, Maibach HI: Immediate contact reactions (contact urticaria syndrome). In: Maibach HI, ed. Occupational and industrial dermatology. 2nd ed. Chicago, IL: Year Book Medical Publishers Inc, 1987:32-44.

34. Menne T, Hjorth N. Reactions from systemic exposure to contact allergens. Semin Dermatol 1982; 1:15-24.

35. Turjanmaa K: Latex glove contact urticaria. Tampere (Finland): University of Tampere, 1988. (Acta Universitatis Tamperensis; ser A, vol 254.)

36. Kanerva L, Jolanki R, Estlander T. Occupational dermatitis due to an epoxy acrylate. Contact Dermatitis $1986 ; 14: 80-4$.

Received for publication: 21 September 1990 